Article

\title{
Chitosan Nanoparticles as Carriers for the Delivery of ФKAZ14 Bacteriophage for Oral Biological Control of Colibacillosis in Chickens
}

\author{
Kaikabo Adamu Ahmad ${ }^{1,2}$, AbdulKarim Sabo Mohammed ${ }^{1, *}$ and Farida Abas ${ }^{1}$ \\ 1 Faculty of Food Science and Technology, Universiti Putra Malaysia, Serdang 43300, Selangor, Malaysia; \\ karkafa@yahoo.co.uk (K.A.A.); faridah_abas@upm.edu.my (F.A.) \\ 2 Bacteriology Research Department, National Veterinary Research Institute, P.M.B 01, Vom 930103, Nigeria \\ * Correspondence: karimsabo@upm.edu.my; Tel.: +60-3-8946-8537; Fax: +60-3-8942-3552
}

Academic Editor: Massimiliano Fenice

Received: 30 November 2015 ; Accepted: 10 February 2016 ; Published: 14 March 2016

\begin{abstract}
The use of chitosan as a delivery carrier has attracted much attention in recent years. In this study, chitosan nanoparticles (CS-NP) and chitosan- $\Phi$ KAZ14 bacteriophage-loaded nanoparticles (C- $\Phi K A Z 14 ~ N P)$ were prepared by a simple coercavation method and characterized. The objective was to achieve an effective protection of bacteriophage from gastric acids and enzymes in the chicken gastrointestinal tract. The average particle sizes for CS-NP and C- $\Phi K A Z 14$ NP were $188 \pm 7.4$ and $176 \pm 3.2 \mathrm{~nm}$, respectively. The zeta potentials for CS-NP and C- $\Phi K A Z 14 \mathrm{NP}$ were 50 and $60 \mathrm{mV}$, respectively. Differential scanning calorimetry (DSC) of C- $\Phi K A Z 14$ NP gave an onset temperature of $-17.17^{\circ} \mathrm{C}$ with a peak at $17.32{ }^{\circ} \mathrm{C}$ and final end set of $17.41^{\circ} \mathrm{C}$, while blank chitosan NP had an onset of $-20.00{ }^{\circ} \mathrm{C}$ with a peak at $-19.78^{\circ} \mathrm{C}$ and final end set at -20.47 . FT-IR spectroscopy data of both CS-NP and C- $\Phi K A Z 14$ NP were the same. Chitosan nanoparticles showed considerable protection of ФKAZ14 bacteriophage against degradation by enzymes as evidenced in gel electrophoresis, whereby ФKAZ14 bacteriophage encapsulated in chitosan nanoparticles were protected whereas the naked ФKAZ14 bacteriophage were degraded. C- $\Phi$ KAZ14 NP was non-toxic as shown by a chorioallantoic membrane (CAM) toxicity assay. It was concluded that chitosan nanoparticles could be a potent carrier of $\Phi K A Z 14$ bacteriophage for oral therapy against colibacillosis in poultry.
\end{abstract}

Keywords: chitosan nanoparticles; bacteriophage; colibacillosis; chickens

\section{Introduction}

Escherichia coli is one of the most common inhabitants of the gastrointestinal tract and other mucosal surfaces of chickens. Some Escherichia coli that are regarded as commensal are useful microbiota, but other strains are said to be pathogenic. The group termed as avian pathogenic Escherichia coli, have the ability to cause an intestinal disease in poultry referred to as colibacillosis $[1,2]$. There are many circulating serotypes of avian pathogenic Escherichia coli; the most commonly encountered are $\mathrm{O} 1, \mathrm{O} 2$, and $\mathrm{O} 78$, and to a lesser extent $\mathrm{O} 15$ and $\mathrm{O} 55$, which are all linked with colibacillosis in chickens [3]. The disease results in high economic losses to the poultry industry worldwide mainly due to its high morbidity and mortality rates. Antibiotics have been used as a control option, but this is limited by the emergence of antibiotic resistance [4].

Bacteriophages are viruses that attack and cause bacterial lysis. They are specific for the host they infect and kill, and therefore they don't have any effect on other living organisms besides bacteria, making them an attractive alternative to antibiotics that could be used to overcome both the bacterial infection and the problem of antibiotic resistance [5]. However, one constraint that could limit the application of phage by oral route is the fact that the effectiveness of administered phage is rapidly 
reduced by acid, enzymes and bile [6], hence a need to protect phage intended for oral therapy to control colibacillosis [7]. It is envisaged that loading phage in chitosan nanoparticles would improve protection from inactivation by enzymes and enhance effective delivery to the target site.

Chitosan and its derivatives are natural polycationic polysaccharides that have been used in various applications and contain glucosamine and $N$-acetylglucosamine units. Yang et al. [8] in their review stated that chitosan could be processed in different nanomaterial forms that have enormous potential to be applied as drug delivery systems, tissue engineering scaffolds, wound dressing adhesives, antimicrobial agents, and biosensors. More recently an application as synergistic theranostics agent has been discussed [9]. Chitosan has been showed to be non-toxic, biocompatible and biodegradable [10]. Even though it has low oral toxicity [11,12], this may depend on the degree of deacetylation, molecular weight, purity, and route of administration. In this study, the preparation and characterization of C- $\Phi$ KAZ14 NP as a carrier system for bacteriophage $\Phi K A Z 14$ for oral application in the biological control of colibacillosis in chickens is discussed.

\section{Results}

\subsection{Bacteriophage Propagation and Titration}

The isolation and characterization of $\Phi K A Z 14$ bacteriophage was reported earlier [13]. The final concentration used for the formulation of C- $\Phi$ KAZ14 NP was $10^{7}$ plaque forming units per milliliter (PFU/mL).

\subsection{Bacteriophage Encapsulation Efficiency}

The encapsulation efficiency was found to be $92 \%$. This means about $92 \%$ of $10^{7} \mathrm{PFU} / \mathrm{mL}$ was encapsulated in the chitosan nanosolution.

\subsection{Scanning Electron Microscopy}

Scanning electron microscopy (SEM) was used to determine the morphology of the C- $\Phi$ KAZ14 NPs. Morphologically the nanoparticles were spherical in shape, with an average size of $100 \mathrm{~nm}$ (Figure 1), although a slight variation in size was observed by measurement with a zetasizer which gave average particle sizes of $176 \pm 3.2$ and $188 \pm 7.4 \mathrm{~nm}$ for C- $\Phi K A Z 14 \mathrm{NP}$ and blank C-NP, respectively.

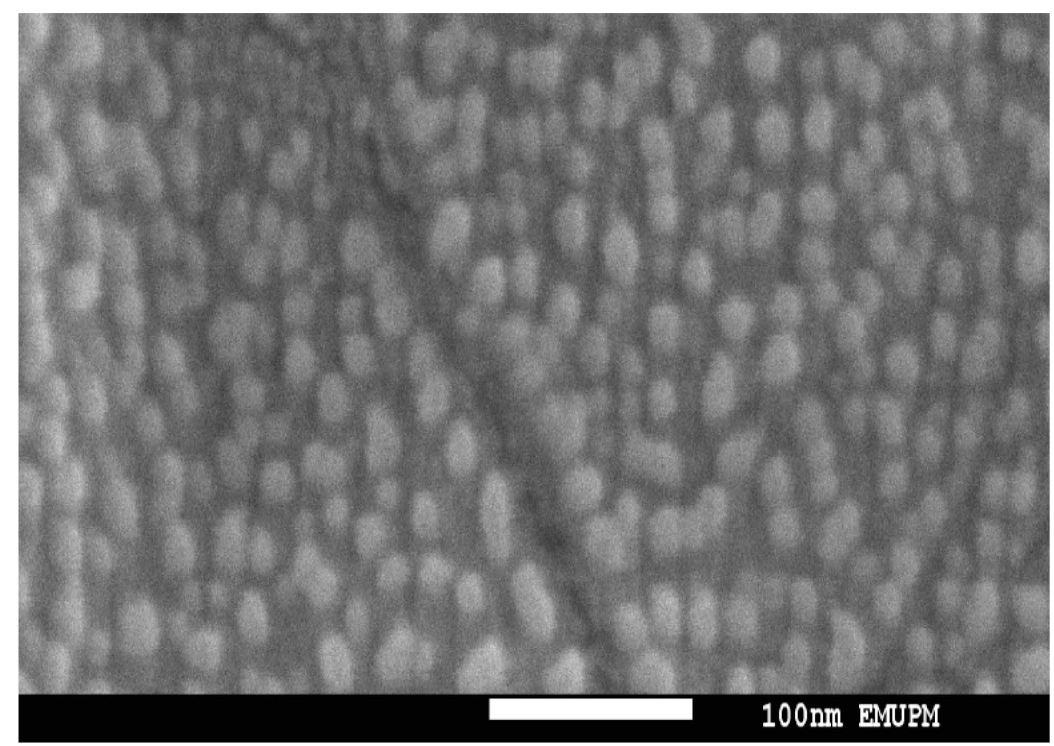

Figure 1. Scanning electron microscopy image of C-ФKAZ14. 


\subsection{Determination of the Size of C- $\Phi K A Z 14 N P$}

The particle sizes of C- $\Phi$ KAZ14 NP and C-NP were found to be less than $200 \mathrm{~nm}$. Positive zeta potential was observed for both C- $\Phi$ KAZ14 NP and C-NP (Table 1).

Table 1. Size, zeta potential, polydispersity index, viscosity and other characteristics of the bacteriophage-based chitosan nanoformulation and blank chitosan nanoparticles.

\begin{tabular}{ccc}
\hline Measurements & Chitosan- $\Phi$ KAZ14 & Chitosan-Blank \\
\hline Size $(\mathrm{nm})$ & $176 \pm 3.2$ & $188 \pm 7.4$ \\
Zeta potential $(\mathrm{mV})$ & $60.3 \pm 0.2$ & $50.5 \pm 0.4$ \\
Polydispersity index & 0.506 & 0.472 \\
pH 7.8 & 7.8 & 7.8 \\
Viscosity $(\mathrm{cP})$ & 0.8872 & 0.8872 \\
Refractive index & 0.01 & 0.01 \\
Temperature $\left({ }^{\circ} \mathrm{C}\right)$ & $25 \pm 0.5$ & $25 \pm 0.5$ \\
\hline
\end{tabular}

2.5. Fourier Transform Infrared Spectroscopy of Chitosan- $\Phi$ KAZ14 Bacteriophage Loaded Nanoparticles

The spectral data recorded during Fourier transform infrared (FT-IR) spectroscopy experiments is shown below (Figure 2). There was no difference between the spectra of the C- $\Phi$ KAZ14 NP and C-NP samples.

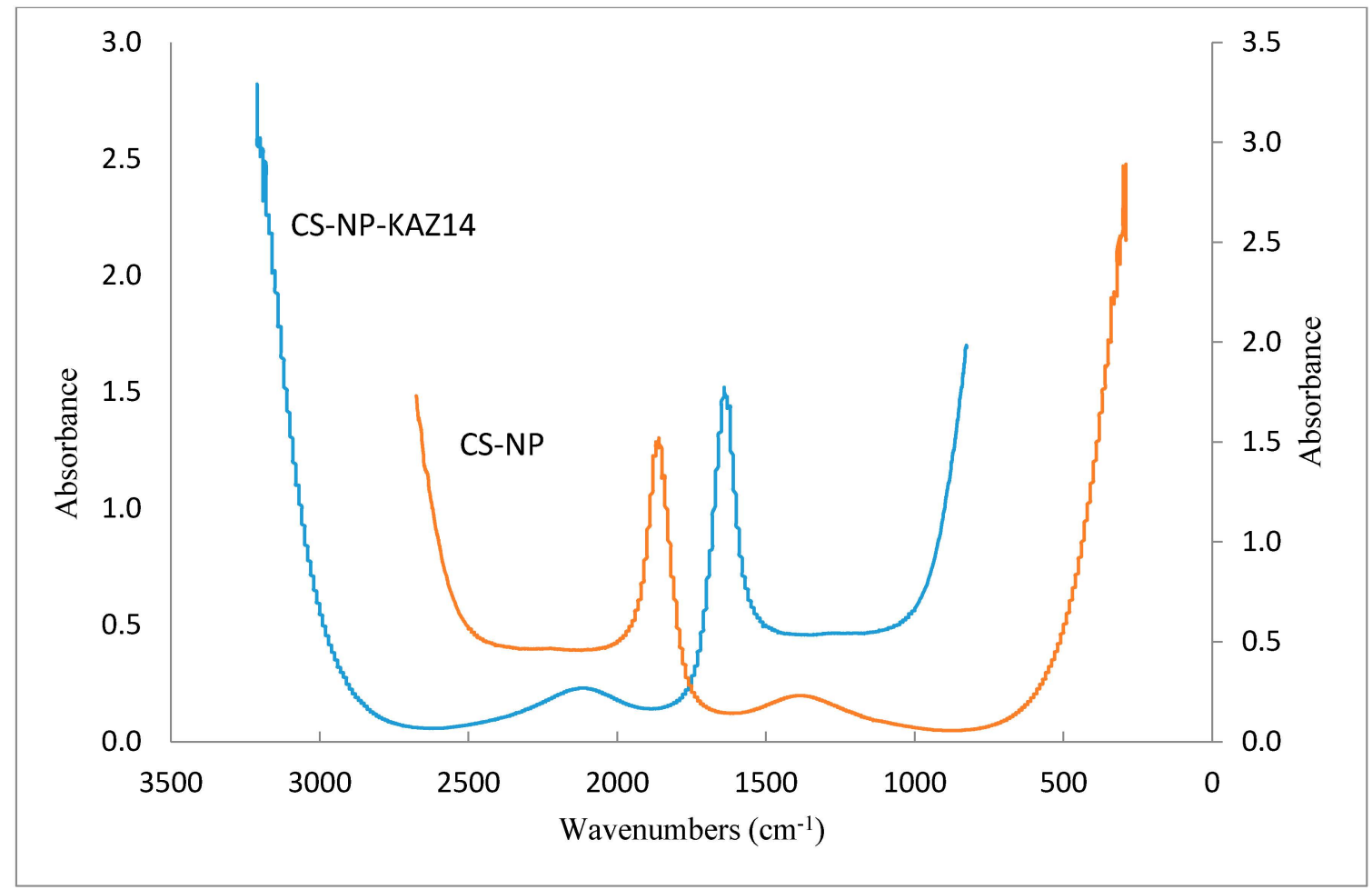

Figure 2. Fourier transform infrared (FT-IR) spectra of blank C-NP and C-ФKAZ14 NP.

\subsection{Protection of Bacteriophage by Chitosan Nanoparticle Encapsulation against Enzyme}

Gel electrophoresis results of enzyme-treated chitosan encapsulated and free phage particles are shown in Figure 3. No observable effect of enzyme is seen on chitosan-encapsulated phage (A), but free phage particles (B) were degraded by enzyme as shown in the gel electrophoresis image. 


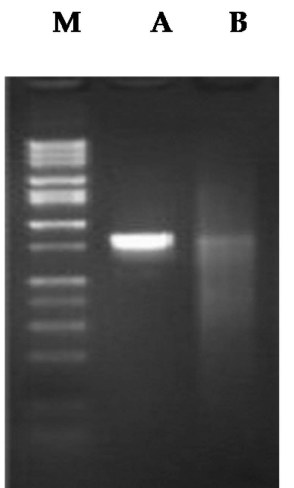

Figure 3. Gel electrophoresis picture of C- $\Phi K A Z 14$ NP (A) and naked $\Phi K A Z 14$ bacteriophage (B) treated with the enzyme pepsin and incubated at $45^{\circ} \mathrm{C}$ for $10 \mathrm{~min}$.

\subsection{Differential Scanning Calorimetry (DSC) of Chitosan- $\Phi K A Z 14$ Bacteriophage Loaded Nanoparticles}

The differential scanning calorimetry (DSC) results are provided in Table 2. The formulated C-NP showed an onset temperature of $-20.00{ }^{\circ} \mathrm{C}$ and crystalized at the endset temperature of $-20.47^{\circ} \mathrm{C}$ while in the C- $\Phi$ KAZ14 NP sample there was a shift in temperature from onset $-17.41^{\circ} \mathrm{C}$ to endset $-17.46{ }^{\circ} \mathrm{C}$. This means the formulated C- $\Phi \mathrm{KAZ} 14 \mathrm{NP}$ could be stable at $-20{ }^{\circ} \mathrm{C}$ without deterioration. The variations in temperatures between C- $\Phi$ KAZ14 NP and C-NP samples could be due to the loading of $\Phi K A Z 14$ particles causing a slight shift of endset thermal peaks in C- $\Phi$ KAZ14 NP and C-NP respectively.

Table 2. Differential scanning calorimetry (DSC) of bacteriophage-based chitosan nanoformulation.

\begin{tabular}{ccc}
\hline Temperature $\left({ }^{\circ} \mathbf{C}\right)$ & Chitosan- $\Phi$ KAZ14 & Chitosan-Blank \\
\hline Onset & -17.61 & -20.00 \\
Peak & -17.32 & -19.78 \\
End set & -17.41 & -20.47 \\
\hline
\end{tabular}

\subsection{Protection Efficiency of Chitosan- $\Phi K A Z 14$ Bacteriophage against Simulated Gastric $p H$}

The C- $\Phi$ KAZ14 NP was not affected by lower $\mathrm{pH}$ 1-4 compared with naked bacteriophage ФKAZ14, which viability decreased at lower $\mathrm{pH}$ (Figure 4).

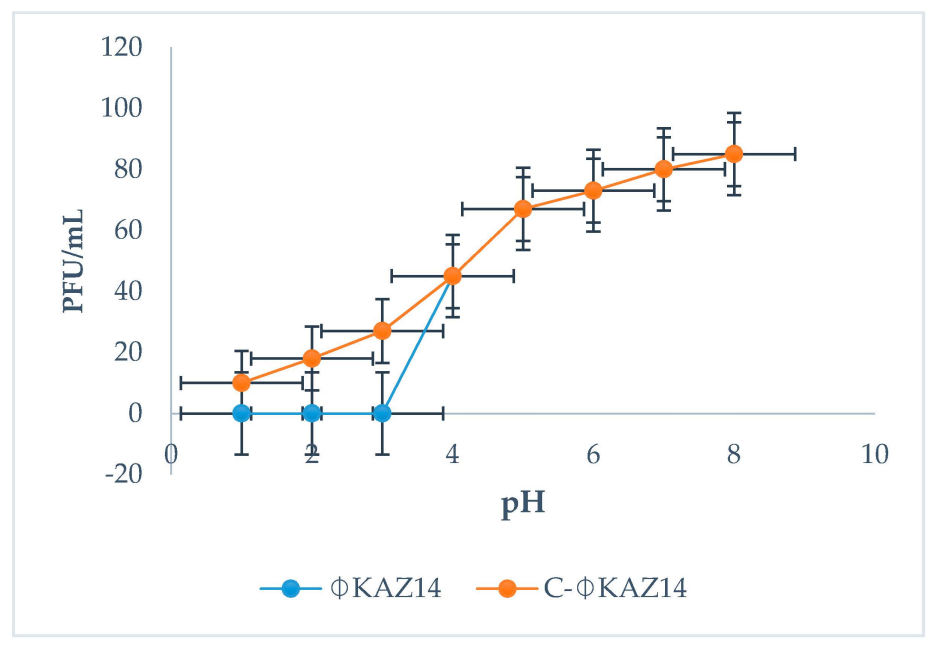

Figure 4. Stability of $\Phi K A Z 14$ bacteriophage under different $\mathrm{pH}$ conditions. 


\subsection{Evaluation of Toxicity of C- $\Phi K A Z 14$ NP Using the Chorioallantoic Membrane (CAM) Assay}

Toxicity of C- $\Phi$ KAZ14 NP was evaluated, and no lethal effects was observed on the growing embryo (Figure 5). However, toxic effects such as hemorrhages, neoangiogenesis or ghost vessels and embryo death were observed in eggs inoculated with 99.8\% glacial acetic acid (Friedman Schmidt Chemical, Parkwood, WA, USA) (Figure 6).

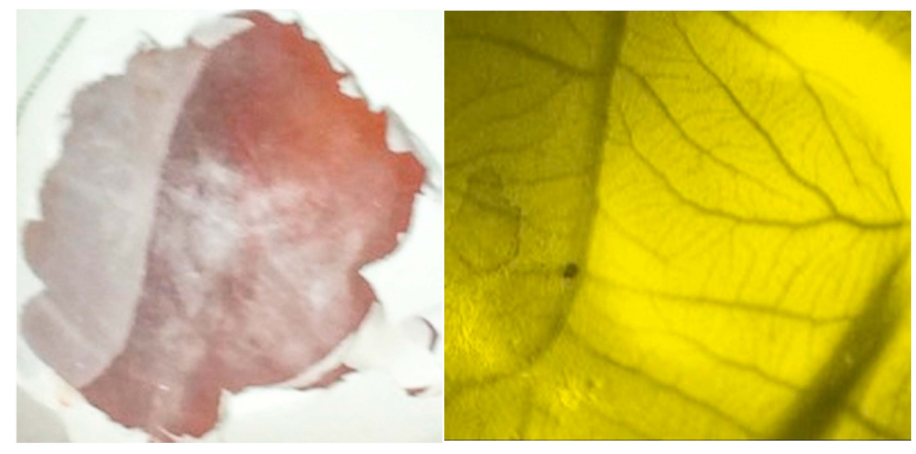

Figure 5. Macroscopic and microscopic images of normal chorioallantoic membrane (CAM) after inoculation with C- $\Phi$ KAZ14 NP and incubation for $24 \mathrm{~h}$. No signs of toxicity were observed on the CAM surface. The embryo survived after $24 \mathrm{~h}$ of incubation.
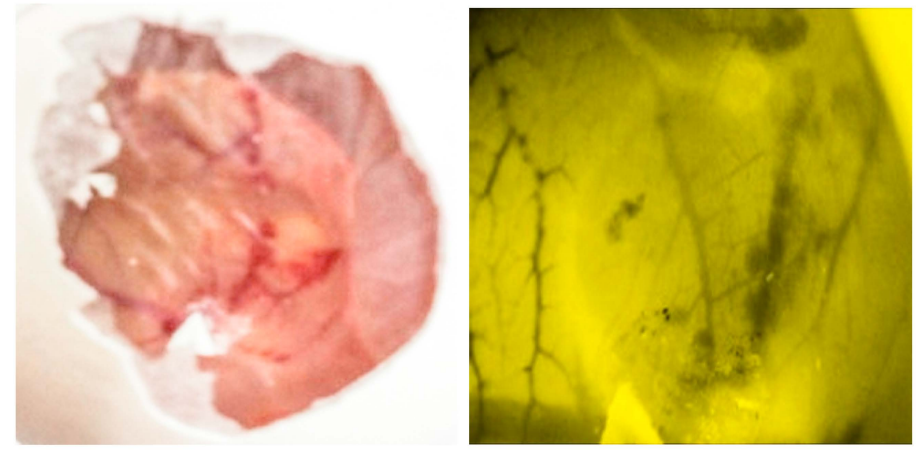

Figure 6. Macroscopic and microscopic images of chorioallantoic membrane (CAM) following inoculation with $99.8 \%$ glacial acetic acid and incubation for $24 \mathrm{~h}$. Note the signs of hemorrhages, ghost vessels, and neoangiogenesis on the CAM surface. The embryo died after $24 \mathrm{~h}$ of incubation.

\section{Discussion}

The main aim of this work was to develop a chitosan-based nanoparticle carrier for the delivery of bacteriophage to control colibacillosis infections in chickens. Colibacillosis is an infectious disease cause by Escherichia coli, it affects poultry worldwide, causing untoward economic losses to poultry farmers. Currently, antibiotic therapy and vaccination remain the only control options for. However, the development of antibiotic resistant strains has become a limiting factor and a problem for the control of this infection. Vaccines are not always reliable because of the problem of the large number of circulating serotypes which need to be identified and incorporated into the vaccine. Thus, homologous serotypes cannot protect against heterologous vaccination [14]. A new alternative approach to control this infection is the application of bacteriophage(s). They are viruses capable of specifically infecting and killing bacteria, and they are not harmful to human, animals, or plants $[15,16]$. Bacteriophage therapy is effective, but is not without issues, particularly in oral application. Some issues associated with oral application of bacteriophage as a therapeutic option are inactivation and degradation of bacteriophage particles by gastric enzymes and acids [17]. Considering that encapsulation of bacteriophage in chitosan nanoparticles could protect bacteriophage against the harsh gastrointestinal conditions and enhance delivery to the target site to achieve good results, in this study, a C- $\Phi K A Z 14$ 
NP was prepared and characterized for application in the biological control of colibacillosis infection in chickens.

Particle size evaluation showed that the formulated C- $\Phi$ KAZ14 NP was below $200 \mathrm{~nm}$ in size $(176 \pm 3.2-188 \pm 7.4 \mathrm{~nm}$, Table 1). Similarly, scanning electron microscopy revealed the size of the formulated C- $\Phi K A Z 14 \mathrm{NP}$ as $100 \mathrm{~nm}$ (Figure 1). These results are in concordance with the reports of Ferrari [18] and Duncan [19] who stated that a nanometer scale complex system for medical applications or drug delivery should have a size range from 10-1000 nm and should consist of two components, one of which should be a pharmaceutically active component. This approved C- $\Phi$ KAZ14 $\mathrm{NP}$ as a particle within the nanosize range. This contradicts reports which state that a particle for medical use could be considered a nanoparticle if it has a size of $\leqslant 100 \mathrm{~nm}$ [18], but it is in congruent with the reports which claim that a range between 170 to $580 \mathrm{~nm}$ qualifies as a nanoparticle. It could be inferred that variations in sizes could arise due to differences in preparation techniques, $\mathrm{pH}$ of the medium, and raw material used [16,19].

The average zeta potentials of C- $\Phi$ KAZ14 NP and CS-NP measured at pH 6.5 were $60.3 \pm 0.2$ and $50.5 \pm 0.4 \mathrm{mV}$, respectively. This showed that complexation of negatively charged bacteriophage with positively charged chitosan did not affect the charge of the finished product and hence the zeta potential. It is likely that the strong positive charges recorded in zeta potential measurements could be due to chitosan which is known to display with high positive charges in a $\mathrm{pH}$ range of 5-6 following protonation of its amino groups in acetic acid milieu. Thus the results agree with the findings of Saied and Aïder [20] who reported that a positive surface charge is obtained for chitosan in the $\mathrm{pH}$ range from 1 to 7 , but they differed from their report that the highest zeta potential values were obtained at $\mathrm{pH}<5$ and that it decreased significantly at $\mathrm{pH} 6$ and 7 .

The FT-IR analysis results (Figure 2) showed no differences between the spectra of bacteriophageloaded and blank chitosan nanoparticles. A similar observation was previously reported by Dehghan et al. [21]. Even with the complexation of CS-NP with SKAZ14 bacteriophage, no shift was observed in the IR bands of C- $\Phi K A Z 14$ NP compared with the blank CS-NPs sample, showing that the chemical integrity of chitosan remained unaltered. Liu et al. [22] reported a slight variation of chemical shift when DNA was incorporated into chitosan nanoparticles. The chemical shift and spectral variation were thought to be due to competitive displacement after loading of the DNA. It is probable that competitive displacement did not occur in this case.

Storage temperature remains the most important factor which influences bacteriophage activity. As in bacteriophage storage, it also determines the stability and purity for nanoparticle storage and handling. Therefore, DSC was used to evaluate the thermostablity of C- $\Phi$ KAZ14 NPs in relation to blank CS-NPs. It was observed that it had an onset temperature of $-20.00{ }^{\circ} \mathrm{C}$ which peaked at -19.78 and an endset at $-20.47^{\circ} \mathrm{C}$ and in C- $\Phi$ KAZ14 NPs the onset temperature was shifted from $-20.47^{\circ} \mathrm{C}$ observed in the normal CS-NPs to an onset temperature of $-17.41^{\circ} \mathrm{C}$, then it peaked at $-17.32{ }^{\circ} \mathrm{C}$ and the endset was seen at $-17.46^{\circ} \mathrm{C}$. In all this then means the formulated C- SKAZ14 NPs could easily be stored and withstand the temperature of $-20^{\circ} \mathrm{C}$ without deterioration. In previous characterization of $\Phi K A Z 14$ bacteriophage it was observed that the viability of cells was not affected significantly by storage at a temperature of $-80^{\circ} \mathrm{C}$ for one month and similarly incubating the phage at a temperature from $50^{\circ} \mathrm{C}$ and below for $24 \mathrm{~h}$ did not affect its viability. However, at a temperature above $50^{\circ} \mathrm{C} \Phi \mathrm{KAZ14}$ bacteriophage were completely inactivated (data not shown). Thus, $\Phi \mathrm{KAZ14}$ bacteriophage could withstand an extreme temperature of $50^{\circ} \mathrm{C}$ and lower temperatures of $-20^{\circ} \mathrm{C}$ and $-80^{\circ} \mathrm{C}$ respectively. These are possible conditions required for the storage of this formulated loaded $\Phi K A Z 14$ bacteriophage product to remain viable. Consistent with this finding, Golec et al. [23] have demonstrated that tailed phages could be stored inside infected cells at $-80^{\circ} \mathrm{C}$ without a major loss of phage and host viability, which may seem a similar scenario to encapsulation of SKAZ14 bacteriophage in CS-NPs where it remained protected and maintained its viability under similar storage conditions. Similarly, Escherichia coli bacteriophage T4 (ATCC ${ }^{\circledR} 11303-B 41^{\mathrm{TM}}$, Manassas, VA, USA). could be stored in a frozen state at a temperature of $-80^{\circ} \mathrm{C}$ or colder or freeze-dried temperature at $2{ }^{\circ} \mathrm{C}$ or $8{ }^{\circ} \mathrm{C}$, respectively, for a short term. 
In the report of Prigent et al. [24] bacteriophages of the family Myoviridae to which $\Phi K A Z 14$ bacteriophage belongs are distinctly resistant to a dry environment and may survive large temperature fluctuations as observed in this study. Again, some T4-like phages similar to ФKAZ14 were reported to be very resistant to long-term storage for years according to Ackermann et al. [25] and survive freezing at $-196^{\circ} \mathrm{C}$ [26]. Ackermann et al. [25] have demonstrated that tailed phages like T4, T5, and T7 were the most resistant to storage and showed the longest survivability; some of them retained viability even after 10-12 years at $4{ }^{\circ} \mathrm{C}$, and up to 32 years as shown for T4-like Shigella phage $\mathrm{C} 16$ which maintained a titre of $10^{3}$ under the same conditions. Therefore, to protect bacteriophages from inactivation over a long period, preservation at $-80^{\circ} \mathrm{C}$ is recommended. In contrast Warren and Hatch [27] did not recommend preserving bacteriophage at a storage temperature of $-20^{\circ} \mathrm{C}$ because the crystal structure of ice may cause destruction of the phages. Nevertheless, Olson et al. [28] have demonstrated that addition of $5 \%-10 \%$ glycerol to a phage suspension may guarantee viability and infectivity for 30 days at $-20^{\circ} \mathrm{C}$ or $-70^{\circ} \mathrm{C}$. Even though we did not add glycerol, the encapsulated $\Phi$ KAZ14 bacteriophage maintained viability at $-20^{\circ} \mathrm{C}$ in CS-NPs which is likely due to the protection conferred by CS-NPs, and $\Phi$ KAZ14 bacteriophage was observed to be viable after one month of storage at $-20^{\circ} \mathrm{C}$.

One major reason that informed the objective of encapsulation of $\Phi K A Z 14$ bacteriophage in CS-NPs, besides effective delivery to the target site, was protection of $\Phi$ KAZ14 bacteriophage from the degradation effects of enzymes, acids, and gastric juice when administered orally. Oral administration leads to a drop in the viability of phages and they end up inactivated. The results obtained in this study have demonstrated that encapsulation of $\Phi K A Z 14$ bacteriophage in CS-NPs as a carrier protects the bacteriophage from enzymatic degradation compared with naked $\Phi K A Z 14$ bacteriophage which were degraded by enzyme in vitro. This finding tallies with earlier reports from Liu et al. [22]. This showed the potential of CS-NPs in protecting $\Phi K A Z 14$ bacteriophage against degradation by the enzyme pepsin in vitro.

C- $\Phi K A Z 14$ NPs were evaluated for biocompatibility and toxicity using a chorioallantoic membrane (CAM) assay, which has considerable advantages of lower cost with significant efficiency and faster measurements than other in vivo assays [29]. In this study, the CAM assay was performed to study the biocompatibility of the starting materials and C- $\Phi$ KAZ14 NPs, assessing microscopic toxicity effects such as hemorrhages, neoangiogenesis and presence of ghost cells and embryo survival following inoculation and incubation of embryonated eggs after $24 \mathrm{~h}$. Both blank CS-NPs and C- $\Phi K A Z 14$ NPs showed no toxic effects or vascular changes such as hemorrhages, neoangiogenesis or ghost vessels on CAM. All embryos were still alive as observed by the embryo response when light was cast on them for microscopic imaging. Rampinno et al. [30] have reported similar observations. However, embryonated eggs inoculated with $99.8 \%$ glacial acetic acid as control showed the presence of hemorrhages, neoangiogenesis, ghost vessels and embryo death $24 \mathrm{~h}$ after inoculation. Glacial acetic acid at a concentration above $50 \%-80 \%$ was reported to have harmful effects on human and animals [31]. In the preparation of CS-NPs for this study, only $1 \%$ acetic acid was used and the fact that tripolyphosphate (TPP) was not used as in previous study $[12,30]$ might also be the reason why toxic effects were avoided. Rampinno et al. [30] have observed toxic effects in TPP used as a starting material for the fabrication of chitosan nanoparticles.

\section{Experimental Section}

\subsection{Preparation of Chitosan Nanoparticles}

A low molecular medium molecular weight chitosan with degree of deacetylation of $75 \%-85 \%$ was purchased (Sigma-Aldrich, St. Louis, MO, USA) and used to prepare chitosan nanoparticles. Briefly, $1 \%$ chitosan nanoparticles were prepared by dissolving chitosan $(0.1 \mathrm{~g})$ in distilled water $(10 \mathrm{~mL})$ containing $100 \mu \mathrm{L}$ acetic acid (QRëC ${ }^{\mathrm{TM}}$, Sungai Buloh, Selangor, Malaysia) under continuous magnetic stirring for one hour. The mixture was vortexed and sonicated for 5 and $30 \mathrm{~min}$, respectively. The resulting solution was centrifuged at $10,000 \times g$ and adjusted to a $\mathrm{pH}$ of 5.5 by adding $0.1 \mathrm{M}$ 
sodium hydroxide (Sigma-Aldrich) with gentle swirling as described [12]. The final solution was filtered through a povidone membrane (filter pore size $0.45 \mu \mathrm{M}$ ) and stored at $4{ }^{\circ} \mathrm{C}$ until required.

\subsection{Bacteriophage Propagation and Titration}

A stock of previously isolated and characterized coliphage $\Phi K A Z 14$ preserved at $-80{ }^{\circ} \mathrm{C}[13]$ was propagated and titrated by serial dilution in SM buffer as previously described [32]. Briefly, a log-phase culture of Escherichia coli (O1:K1:H7) was diluted in Tryptose Soy Broth and mixed thoroughly, then the suspension was sprayed onto the surface of TSA plates. Serial 10-fold dilutions of the phage suspension were prepared, and $10 \mu \mathrm{L}$ of each dilution was spotted, in triplicate, onto an inoculated plate. The plates were incubated at $37^{\circ} \mathrm{C}$ overnight, and the plaques present on each plate were counted.

\subsection{Formulation of Chitosan- $\Phi K A Z 14$ Bacteriophage-Loaded Nanoparticles}

$10^{7} \mathrm{PFU} / \mathrm{mL}$ ФKAZ14 bacteriophage was loaded into the chitosan nanoparticles as follows: the bacteriophage suspension $(10 \mathrm{~mL})$ containing $10^{7} \mathrm{PFU} / \mathrm{mL}$ of $\Phi K A Z 14$ bacteriophage particles were suspended in $1 \%$ chitosan solution $(v / v, 10 \mathrm{~mL})$ and gently stirred with a magnetic bar. The homogenous solution was store at $4{ }^{\circ} \mathrm{C}$ until used [33]. At weekly intervals the sample is assayed for the viability of $\Phi K A Z 14$ bacteriophage. To determine the encapsulation efficiency of phage, a spectrophotometric method was used. The spectrophotometric readings of both chitosan- $\Phi$ KAZ14 bacteriophage nanoparticle samples and supernatant after the centrifugation were measured. The encapsulation efficiency was calculated as follows: Encapsulation efficiency $=$ Absorbance of C- $\Phi$ KAZ14 NP (X) - Absorbance of supernatant $(\mathrm{Y}) /$ absorbance of C- $\Phi$ KAZ14 NP(X) $\times 100$. The procedure was repeated thrice, and results calculated as \pm SD.

\subsection{Characterization of Chitosan- $\Phi K A Z 14$ Bacteriophage-loaded Nanoparticles}

\subsubsection{Scanning Electron Microscopy}

The morphology of the prepared chitosan nanoparticle was observed by scanning electron microscopy (SEM). A model JEOL JSM-6400, scanning electron microscope (JEOL, Tokyo, Japan) was used. A drop of chitosan nanoparticle sample was dropped on a parafilm and a carbon coated grid (Agar Scientific, Essex, UK) was placed on the chitosan nanoparticle sample and held for $5 \mathrm{~min}$, this was then fixed in $2 \%$ phosphotungstic acid (PTA, Sigma) for a period of $5 \mathrm{~min}$. The grid was removed and excess liquid was blotted off, it was then dropped on a Whatman filter paper (GE Healthcare, Buckinghamshire, UK) placed in a Petri plate. The grid was dried in a desiccator and viewed under the electron microscope [34].

\subsubsection{Determination of the size of Chitosan- $\Phi K A Z 14$ Bacteriophage-loaded Nanoparticles}

The zeta size and potential of chitosan- $\Phi$ KAZ14 bacteriophage-loaded nanoparticles was measured using a Malvern Zetasizer 3000 instrument (Malvern Instruments, Malvern, UK) as described previously [17]. Briefly, the procedure is as follows; the chitosan- $\Phi$ KAZ14 bacteriophage-loaded nanoparticles sample (about $100 \mu \mathrm{L}$ ) was diluted in miliQ water $(900 \mu \mathrm{L}$ ), sonicated then transferred into a capillary cell. The capillary cell containing the sample was inserted into the machine (Zeta Sizer Nano). The standard operating procedure (SOP) used the following parameters: temperature $25^{\circ} \mathrm{C}$; light scattering angle $90^{\circ} \mathrm{C}$; dispersion $(v)$; refractive index 1.330; viscosity $(\mathrm{cP}) 0.8872$ and dielectric constant 78.5 set on the computer control system and then run for the measurements to be performed and recorded.

\subsubsection{Fourier Transform Infrared Spectroscopy of Chitosan- $\Phi$ KAZ14 Bacteriophage-loaded Nanoparticles}

Fourier transform infrared spectroscopy (FTIR) spectral data of the chitosan- $\Phi K A Z 14$ bacteriophage-loaded nanoparticles and chitosan blank were generated and recorded on a Nicolet iS 50 FT-IR Spectrometer FTIR-Nexus (Thermo Fisher Scientific Inc., Waltham, MA, USA). 
4.4.4. Determination of Thermal Stability and Purity of Chitosan- $\Phi$ KAZ14 Bacteriophage-loaded Nanoparticles

To evaluate the stability and purity of the preparation, differential scanning calorimetry (DSC) was performed using a PYRIS Diamond DSC machine (Perkin Elmer Instruments, Waltham, MA, USA). The instrument measures the amount of energy or heat absorbed or released by a sample when it is heated, cooled or held at constant temperature. It also can perform precise temperature measurements. Thus, about $200 \mu \mathrm{L}$ of the sample was dropped into an aluminum pan, covered and secured firmly so that the sample will not spill when heated. Similarly, an empty pan was used as control. The parameters set in the standard operating procedure were a temperature range from $-40^{\circ} \mathrm{C}$ cooling to $25^{\circ} \mathrm{C}$ heating, then held at $25^{\circ} \mathrm{C}$ to $45^{\circ} \mathrm{C}$ heating. The heating rate was kept at $10^{\circ} \mathrm{C}$ per minute under a continuous nitrogen gas flow at $5 \mathrm{~mL} / \mathrm{min}$. The data was recorded and analyzed using the PYRIS software.

4.4.5. Protection Efficiency of Chitosan against $\Phi$ KAZ14 Bacteriophage Degradation by Enzyme and Simulated Gastric pH

Effects of enzyme on C- $\Phi$ KAZ14 NP and free $\Phi$ KAZ14 bacteriophage was evaluated as described by Dini et al. [35]. Briefly, pepsin (Sigma Aldrich) was purchased and reconstituted to a concentration of $5.0 \mathrm{mg} / \mathrm{mL}$. Reconstituted pepsin solution (some $100 \mu \mathrm{L}$ ) was added to saline solution $(\mathrm{pH} 2.5$, $900 \mu \mathrm{L})$ and free $\Phi$ KAZ14 bacteriophage $\left(10 \mu \mathrm{L}, 10^{7} \mathrm{PFU} / \mathrm{mL}\right)$ and C- $\Phi K A Z 14 \mathrm{NP}$, then all the reagents were mixed in $1.5 \mathrm{~mL}$ centrifuge tube. The mixtures were incubated for $10 \mathrm{~min}$ at $45^{\circ} \mathrm{C}$. Thereafter, the samples were electrophoresed on $0.8 \%$ agarose and viewed on a gel documentation system $\left(\mathrm{Gel}^{\mathrm{Doc}} \mathrm{CM}^{\mathrm{TM}}\right.$ EZ System, BIO-RAD, Hercules, CA, USA).

The stability of $\Phi$ KAZ14 bacteriophage under different $\mathrm{pH}$ conditions was evaluated as described [13]. SM buffer solution was adjusted to $\mathrm{pH}$ of 2, 3, 4, 5, 6, and up to 14 using $1 \mathrm{M}$ $\mathrm{HCl}$. $\Phi \mathrm{KAZ} 14$ bacteriophage suspension $(100 \mu \mathrm{L})$ was added to prewarmed $\left(37^{\circ} \mathrm{C}\right) \mathrm{pH}$-adjusted SM buffer solution $(9.9 \mathrm{~mL})$ to give a concentration of about $10^{7} \mathrm{PFU} / \mathrm{mL}$. After the addition of $\Phi$ KAZ14 bacteriophage, the samples were incubated at $37^{\circ} \mathrm{C}$ for $5 \mathrm{~min}$. Following incubation, $100 \mu \mathrm{L}$ were collected and serially diluted 10-fold, then assayed for bacteriophage viability [35]. The experiment was repeated three times.

\subsubsection{Cytotoxicity by Chorioallantoic Membrane (CAM) Assay}

In vivo biological compatibility of blank C-NP and C-ФKAZ14 NP were evaluated using the chick embryo chorioallantoic membrane (CAM) assay [30]. In this approach, fertilized eggs were disinfected with 70\% alcohol and inoculated with C- $\Phi$ KAZ14 NP and blank C-NP (0.5 mL) directly into the CAM, the opening was sealed and the eggs were incubated at $38{ }^{\circ} \mathrm{C}$ with $60 \%$ humidity for $24 \mathrm{~h}$. Following incubation, the effect of the formulations on the growing embryos was visualized using a WILD M32 stereomicroscope (Leica, Singapore, Singapore) that was equipped with a WILD PLAN 1X lens, this system was connected to a Leica DFC 320 camera system. This system was used to observe the evolution of any effects on the CAM and embryo. After $24 \mathrm{~h}$, all inoculated eggs were observed and images acquired were qualitatively compared to determine the toxicity.

\section{Conclusions}

All the results on the preparation, characterization and stability of C- $\Phi$ KAZ14 NPs as carriers for the delivery of bacteriophage to be used in oral application depend chiefly on the adjustment of the experimental conditions and identified appropriate steps. The simple coercavation method was shown to be effective. The concentration, $\mathrm{pH}$ and time used in stirring to obtain a fully dissolved homogenous mixture of nanoparticles in suspension was important in producing a good average particle size, and the use of vortexing and sonication helped rearrange the micro particles to form Nano sized particles. In trying to ensure both the stability of the nanoparticle characteristics and good protection of loaded $\Phi$ KAZ14, thermal stability studies using DSC helped assess the temperature at which the 
loaded $\Phi K A Z 14$ would not be affected and or inactivated. Toxicity evaluation of nanoparticles is an important aspect, and over the years emphasis has been directed towards evaluation of the safety of nanoparticles for biological membranes with in vivo tests, a consideration that has been mostly disregarded in experiments producing nanoparticles for human or animal use. As an alternative to the use of brine shrimp, acute toxicity tests, and mammalian cells for in vivo tests, CAM assay using chicken embryos has assured the biocompatibility of both chitosan and bacteriophage, and inspired the application of this simple and direct technique in future works. It is direct, easy, non-time consuming and affordable method.

Acknowledgments: This work has been funded by Research University Grant Scheme (RUGS; grant number 9329400), University Putra Malaysia, Selangor, Malaysia.

Author Contributions: A.A.K. conceived, designed and performed the experiments; A.S.M. and F.A. supervised the project. A.A.K. wrote the paper. The project is a PhD work of A.A.K. under the supervision of A.S.M. and F.A.

Conflicts of Interest: No conflict of interest declared by the authors.

\section{References}

1. Kariyawasam, S.; Johnson, T.J.; Nolan, L.K. Unique DNA sequences of avian pathogenic Escherichia coli isolates as determined by genomic suppression subtractive hybridization. FEMS Microbiol. Lett. 2006, 262, 193-200. [CrossRef] [PubMed]

2. Bonnet, C.; Diarrassouba, F.; Brousseau, R.; Masson, L.; Topp, E.; Diarra, M.S. Pathotype and antibiotic resistance gene distributions of Escherichia coli isolates from broiler chickens raised on antimicrobial-supplemented diets. Appl. Environ. Microbiol. 2009, 75, 6955-6962. [CrossRef] [PubMed]

3. Raji, M.; Adekeye, J.; Kwaga, J.; Bale, J.; Henton, M. Serovars and biochemical characterization of Escherichia coli isolated from colibacillosis cases and dead-in-shell embryos in poultry in Zaria-Nigeria. Veterinarski arhiV 2007, 77, 495-505.

4. Salehi, T.Z.; Bonab, S.F. Antibiotics susceptibility pattern of Escherichia coli strains isolated from chickens with colisepticemia in Tabriz province, Iran. Int. J. Poult. Sci. 2006, 5, 677-684.

5. Huff, W.E.; Huff, G.R.; Rath, N.C.; Donoghue, A.M. Method of administration affects the ability of bacteriophage to prevent colibacillosis in 1-day-old broiler chickens. Poult. Sci. 2013, 4, 930-934. [CrossRef] [PubMed]

6. Joerger, R.D. Alternatives to antibiotics: Bacteriocins, antimicrobial peptides and bacteriophages. Poult. Sci. 2003, 82, 640-647. [CrossRef] [PubMed]

7. Chibani-Chennoufi, S.; Sidoti, J.; Bruttin, A.; Kutter, E.; Sarker, S.; Brüssow, H. In vitro and in vivo bacteriolytic activities of Escherichia coli phages: Implications for phage therapy. Antimicrob. Agents Chemother. 2004, 48, 2558-2569. [CrossRef] [PubMed]

8. Yang, Y.; Wang, S.; Wang, Y.; Wang, X.; Wang, Q.; Chen, M. Advances in self-assembled chitosan nanomaterials for drug delivery. Biotechnol. Adv. 2014, 32, 1301-1316. [CrossRef] [PubMed]

9. Peng, H.; Liu, X.; Wang, G.; Li, M.; Bratlie, K.M.; Cochran, E.; Wang, Q. Polymeric multifunctional nanomaterials for theranostics. J. Mater. Chem. B 2015, 3, 6856-6870. [CrossRef]

10. Struszczyk, H.; Wawro, D.; Niekraszewicz, A. Biodegradability of chitosan fibres. In Advances in Chitin and Chitosan; Brine, C.J., Sandford, P.A., Zikakis, J.P., Eds.; Elsevier Applied Science: London, UK, 1991; pp. 580-585.

11. Chandy, T.; Sharma, C.P. Chitosan-as a biomaterial. Biomater. Artif. Cells Artif. Organs 1990, 18, 1-24. [CrossRef] [PubMed]

12. Hirano, S.; Seino, H.; Akiyama, Y.; Nonaka, I. Chitosan: A biocompatible material for oral and intravenous administrations. In Progress in Biomedical Polymers; Springer: Medford, MA, USA, 1990; pp. 283-290.

13. Kaikabo, A.A.; Abdulkarim, S.M.; Faridah, A.; Sieo, C.C. T4-like coliphage $\Phi K A Z 14$ virulent to pathogenic and extended spectrum $\beta$-lactamase-producing Escherichia coli of poultry origin. Virol. Sin. 2015, 31, 73-75.

14. Kabir, S.M. Avian colibacillosis and salmonellosis: A closer look at epidemiology, pathogenesis, diagnosis, control and public health concerns. Int. J. Environ. Res. Publ. Health 2010, 7, 89-114. [CrossRef] [PubMed]

15. Sulakvelidze, A.; Zemphira, A.; Glenn, M. Bacteriophage therapy. Antimicrob. Agents Chemother. 2001, 45, 649-659. [CrossRef] [PubMed] 
16. Dowling, A.; Clift, R.; Grobert, N.; Hutton, D.; Oliver, R.; O'neill, O.; Seaton, A. Nanoscience and Nanotechnologies: Opportunities and Uncertainties. Available online: http://www.nanotec.org.uk/ finalReport.htm (accessed on 26 January 2016).

17. Koo, J.; Angelo, D.; Douglas, L.M. Effect of simulated gastric fluid and bile on survival of Vibrio vulnificus and Vibrio vulnificus phage. J. Food Prot. 2000, 63, 1665-1669. [PubMed]

18. Ferrari, M. Cancer nanotechnology: Opportunities and challenges. Nat. Rev. Cancer 2005, 5, $161-171$. [CrossRef] [PubMed]

19. Duncan, R. The dawning era of polymer therapeutics. Nat. Rev. Drug Disc. 2000, 32, 347-360. [CrossRef] [PubMed]

20. Saïed, N.; Mohammed, A. Zeta Potential and Turbidimetry Analyzes for the Evaluation of Chitosan/Phytic Acid Complex Formation. J. Food Res. 2014, 3, 71. [CrossRef]

21. Dehghan, S.; Kheiri, M.T.; Tabatabaiean, M.; Darzi, S.; Tafaghodi, M. Dry-powder form of chitosan nanospheres containing influenza virus and adjuvants for nasal immunization. Arch. Pharm. Res. 2013, 36, 981-992. [CrossRef] [PubMed]

22. Liu, Z.; Lv, D.; Liu, S.; Gong, J.; Wang, D.; Xiong, M.; Tan, X. Alginic acid-coated chitosan nanoparticles loaded with legumain DNA vaccine: Effect against breast cancer in mice. PLoS ONE 2013, 8, 60-190. [CrossRef] [PubMed]

23. Golec, P.; Joanna, K.-G.; Marcin, Ł.; Grzegorz, W. Novel ZnO-binding peptides obtained by the screening of a phage display peptide library. J. Nanopart. Res. 2012, 14, 1-6. [CrossRef] [PubMed]

24. Prigent, M.; Magali, L.; Fabrice, C.; Murielle, D.; Michael, S.D. A Diversity of bacteriophage forms and genomes can be isolated from the surface sands of the Sahara Desert. Extremophiles 2005, 9, 289-296. [CrossRef] [PubMed]

25. Ackermann, H.-W.; Denise, T.; Sylvain, M. Long-term bacteriophage preservation. WFCC Newslett. 2004, 38, 35-40.

26. Tsutsaeva, A.A.; Bysekantsev, I.P.; IuE, M.; Butenko, A.E. Effect of low temperatures of the survival and intracellular multiplication of Escherichia coli bacteriophages. Mikrobiologiia 1980, 50, 292-294.

27. Warren, J.; Melvin, C.; Hatch, T. Survival of T3 coliphage in varied extracellular environments. I. Viability of the coliphage during storage and in aerosols. Appl. Microbiol. 1969, 17, 256-261. [PubMed]

28. Olson, M.R.; Richard, P.A.; Randall, E.H. Effects of freezing and storage temperature on MS2 viability. J. Virol. Methods 2004, 122, 147-152. [CrossRef] [PubMed]

29. Schoubben, A.; Paolo, B.; Maria, L.; Marenzoni, L.; Barberini, S.; Giovagnoli, C.C.; Maurizio, R. Capreomycin supergenerics for pulmonary tuberculosis treatment: Preparation, in vitro, and in vivo characterization. Eur. J. Pharm. Biopharm. 2013, 83, 388-395. [CrossRef] [PubMed]

30. Rampino, A.; Massimiliano, B.; Paolo, B.; Barbara, B.; Attilio, C. Chitosan nanoparticles: Preparation, size evolution and stability. Int. J. Pharm. 2013, 455, 219-228. [CrossRef] [PubMed]

31. Sweet, D.V. Registry of Toxic Effects of Chemical Substances (RTECS); National Inst. for Occupational Safety and Health: Cincinnati, OH, USA, 1986.

32. Oliveira, A.; Sanna Sillankorva, R.; Quinta, A.; Henriques, R.; Sereno, J.A. Isolation and characterization of bacteriophages for avian pathogenic E. coli strains. J. Appl. Microbiol. 2009, 106, 1919-1927. [CrossRef] [PubMed]

33. Mao, H.Q.; Roy, K.; Troung-Le, V.L.; Janes, K.A.; Lin, K.Y.; Wang, Y.; August, J.T.; Leong, K.W. Chitosan-DNA nanoparticles as gene carriers: Synthesis, characterization and transfection efficiency. J. Control. Release 2001, 70, 399-421. [CrossRef]

34. Gåserød, O.; Olav, S.; Gudmund, S. Microcapsules of alginate-chitosan-I: A quantitative study of the interaction between alginate and chitosan. Biomaterials 1998, 19, 1815-1825.

35. Dini, C.; Islan, G.A.; de Urraza, P.J.; Castro, G.R. Novel biopolymer matrices for microencapsulation of phages: Enhanced protection against acidity and protease activity. Macromol. Biosci. 2012, 12, 1200-1208. [CrossRef] [PubMed]

Sample Availability: Sample of C- $\Phi$ KAZ14 NP is available from the authors.

(C) 2016 by the authors; licensee MDPI, Basel, Switzerland. This article is an open access article distributed under the terms and conditions of the Creative Commons by Attribution (CC-BY) license (http://creativecommons.org/licenses/by/4.0/). 